\title{
Enriching the teaching of fractions through integrating mathematics and music
}

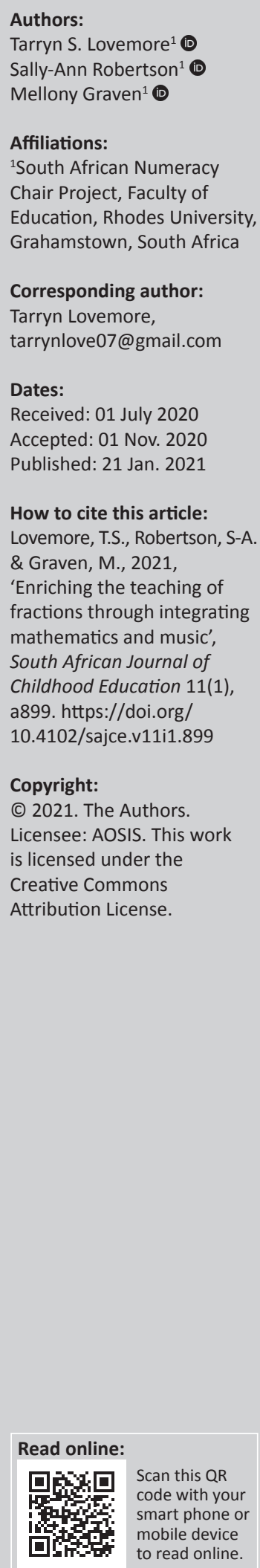

Background: Mathematics education is a significant issue in the South African context. Learners' achievement levels are markedly low as suggested by both national and international studies. The teaching and learning of fractions in particular have been identified as challenging.

Aim: The aim of this article is to share some of the outcomes derived from a series of lessons in which aspects of music (note values) were integrated into the teaching of fractions in primary school.

Setting: The study was conducted in a Grade 5 class in an independent school in the Eastern Cape, with readily available resources at hand.

Methods: The broader study was an action research case study. It employed qualitative methods of data collection, based on cycles of critical reflection and adjustment, including feedback from learners and critical peers.

Results: Findings highlighted the value of integrating music and mathematics as a teaching and learning strategy. Learning support materials and activities that promoted curriculum integration were designed. The discussion highlights benefits of these integrated lessons.

Conclusion: We conclude by suggesting that teachers explore synergistic opportunities across mathematics and music as subjects. In particular, we suggest curriculum integration to support the teaching of fractions in the primary grades of schooling. Our hope is that this article will encourage teachers to develop their own integrated strategies for enriching their teaching of mathematics.

Keywords: Grade 5; curriculum integration; note values; Bresler's co-equal cognitive style of arts integration; qualitative study; action research; multiple representations; motivation.

\section{Introduction}

Evidence from the international comparative Trends in Mathematics and Science Study (TIMSS) supports the claims that many teachers find teaching mathematics challenging and that many South African learners face obstacles learning mathematics. The 2015 TIMSS report, for example, indicated that $61 \%$ of Grade 5 learners in South Africa could not do basic mathematics, ranking these learners as the lowest performing of the participating countries (Mlachila \& Moeletsi 2019; Spaull 2018). For our own province (Eastern Cape), the 2015 TIMSS indicated that the percentage of Grade 5 learners who were unable to demonstrate basic mathematics knowledge and skills was even higher (74\%) (Reddy et al. 2016). The TIMSS 2019 results, released on 08 December 2020, indicated minimal change in the Grade 5 learners' achievement average, which remains below the basic threshold of 400 TIMSS points (Reddy et al. 2020).

South Africa's matriculation results for mathematics are also a cause for concern. Only $58 \%$ of learners taking mathematics in 2018 achieved the over 30\% level (Department of Basic Education [DBE] 2019:132). In 2019, only 54.6\% of matric learners achieved the over 30\% level (DBE 2020:5). These statistics say nothing, however, of the substantial attrition rate in the number of learners actually taking mathematics in the years preceding matric (Adler \& Pillay 2017), and Shay (2020) notes that the situation is not improving because of a further increase in attrition of $17.9 \%$ from 2018 to 2019.

Our focus for this article is on the use of music in the teaching of fractions at Grade 5 level. As literature indicates, fractions form an integral part of foundational knowledge for mathematics achievement, especially the development of fractional reasoning (Cortina, Visnovska \& Zuniga 2014; Dole 2010; Hilton et al. 2016; Tzur 2016); yet, developing a sound understanding of fractional 
knowledge is identified as being particularly challenging (Tzur 2016). Literature demonstrates many connections between music and mathematics as well as the benefits using these links can have for education (Civil 2007; Edelson \& Johnson 2003; Geist, Geist \& Kuznik 2012; Song et al. 2016).

A number of previous studies have suggested possible ways in which musical activities can be used to support mathematics teaching and learning. For example, research by Bresler (1995) identified four different ways in which arts were integrated into other primary school subjects, depending on how the teacher used the various arts forms. She named the different styles of arts integration as the subservient approach, the affective style, the social integration style and the co-equal, cognitive style. The first three styles of integration involve using the arts to illustrate content, to enhance a particular atmosphere within the classroom or to create meaningful links to the community surrounding the school, respectively. The co-equal, cognitive style (which, for the remainder of this article, we refer to as the 'co-equal style' as per Bresler's abbreviation in her own work) was identified as the most rigorous, but least prevalent style, because it requires that teachers have the necessary knowledge and skills of the arts form (Bresler 1995; Grumet, Randolph \& Stanley 2014). In a similar study, Song et al. (2016:20) identified and categorised three ways in which teachers integrated music into the mathematics curriculum, namely mathematics as a tool during music creation, music as a catalyst for mathematical cognition and music as a pedagogical approach to mathematics. They note, however, that research exploring the third integration strategy is limited and called for further research aimed at identifying practical strategies that teachers can employ when teaching mathematics at the primary school level (Song et al. 2016).

Both Bresler (1995) and Song et al. (2016) identify the integration of mathematics and music at a pedagogical level to be the most demanding way for teachers to use the two subjects in which it requires that teachers have knowledge, skills and confidence in both subjects, as well as enough time to plan and effectively prepare integrated lessons. Such difficulty notwithstanding, South Africa's Curriculum and Assessment Policy Statement (CAPS) highlights the importance of integration between school subjects (DBE 2011a).

The present study shares elements from the first author's response to this call to begin addressing the gap that exists in research about the integration of mathematics and music at a pedagogical level. The research reported in this article derives from the first author's master of education case study research (Lovemore 2020).

At the time when this research was carried out, the first author taught Grade 5 mathematics. She had also taught class music and violin lessons before the study. Having noticed the mathematics found in music, she recognised an opportunity to explore how music and mathematics could be integrated to support her own teaching of fractions.
Subsequently, using an action research case study, she designed various learning support materials (LSMs) and trialled a range of practical strategies with her Grade 5 mathematics class across eight weeks of teaching.

The concept of curriculum integration and Bresler's styles of arts integration guided the first author through the broader study. Bresler's styles of arts integration (1995) provided the theoretical framing of the study. The author located her research within the co-equal style. This captured the essence of her research goal, namely, to demonstrate possible strategies whereby music note values could be used in creative ways in her teaching of fractions to her Grade 5 learners. We believe her research story may be valuable to other teachers interested in exploring the use of curriculum integration, in particular, integration of music and mathematics. In our concluding section, we discuss some implications for further research in this area.

\section{Support for curriculum integration}

A key motivation for this study as well as for the present article is the aforementioned poor performance levels in mathematics in South Africa. Both the study and the article represent a response to literature, suggesting the need for innovative strategies to be explored in the teaching of fractions, that is, strategies likely to enhance learners' attitudes towards mathematics more generally and thereby encouraging their more active participation in it.

South Africa's CAPS (DBE 2011a) for school mathematics seeks to promote:

- a critical awareness of how mathematical relationships are used in social, environmental, cultural and economic relations;

- a spirit of curiosity and a love for Mathematics;

- an appreciation for the beauty and elegance of mathematics;

- recognition that mathematics is a creative part of human activity;

- deep conceptual understanding in order to make sense of Mathematics;

- acquisition of specific knowledge and skills necessary for ... the study of related subject matter (e.g. other subjects) and further study in Mathematics. (p. 8)

Curriculum integration is explicitly encouraged in South Africa's Department of Education (DoE) curriculum documents. Both the Revised National Curriculum Statement (DoE 2003) and CAPS documents, in this instance the mathematics statement (DBE 2011a), indicate that such integration provides learners with opportunities to experience and establish links across the curriculum and supports the development of skills, knowledge, attitudes and values in a meaningful context. Similarly, the Creative Arts statement, of which music is a part, describes the purpose of music as being to develop learners as 'creative, imaginative individuals', with a focus on the 'inclusive 
nature of the arts' (DBE 2011b:7). The Creative Arts policy document further states that 'integration is fundamental' (DBE 2011b:9).

This curriculum support for integration across subjects provided a strong motivation and an opportune space for the first author's broader study. She recognised that not only did integration of music into mathematics provide an opportunity to meet these curriculum aims but also that having learners work with music note values lent itself particularly well to their simultaneous conceptual work on relative fraction sizes. She was thereby able to enrich not only her own mathematics teaching strategies but also promote her learners' 'acquisition of specific knowledge and skills' (DBE 2011a:8) necessary for the conceptual development of fractions. At the same time, she would be helping them become more critically aware of mathematical relationships in their world and appreciative of the beauty of mathematics and its creative potential in human activity.

\section{The concept of fractions and music note values}

The topic of fractions forms an important part of curricula internationally. It is widely accepted as a difficult topic requiring a great deal of time not only for teaching, but also for addressing misconceptions (Cortina et al. 2019). Many learners, for example, may think of a fraction as consisting of two numbers separated by a line as opposed to seeing it as representing a single number with a single position on a number line (Musser, Burger \& Peterson 2011). In responding to challenges posed by such misconceptions, and noting that the concept of a fraction is 'a complex, multifaceted idea involving a variety of meanings that relate to each other in an intricate manner' (Thompson \& Saldanha 2003 in Cortina et al. 2019:20), Cortina et al. (2019) advocate a shift from teaching fractions through rote procedures to teaching for more conceptual understanding and for developing proportional forms of reasoning.

The term 'fraction', as Musser et al. (2011:218) explain, is used in two different ways in primary school mathematics: as a numeral (the 'part-to-whole model' indicating the number of parts of a whole) or as a number where the focus is on a relative amount. We see music as constituting an ideal vehicle through which an integrated teaching approach could be employed to create potentially richer fraction-learning opportunities. Music is made up of notes, which vary in duration, known as the note value. Note values are expressed as 'relative lengths to one another' and their 'fraction-like names imply, the relative values' (Kornfeld 2005:10). Hence, as shown in Figure 1, a whole note is equivalent to two half notes or four quarter notes or eight eighth notes.

\section{Theoretical framing of curriculum integration and Bresler's arts integration}

A literature review and analysis of curriculum expectations around the concept of curriculum integration were integral
FIGURE 1: Representation of note value names and relative durations.

\begin{tabular}{llll}
\hline $\begin{array}{l}\text { Musical } \\
\text { notation } \\
\text { naming } \\
\text { conventions: } \\
\text { British-English }\end{array}$ & $\begin{array}{l}\text { Musical notation } \\
\text { naming } \\
\text { conventions: } \\
\text { name }\end{array}$ \\
\hline $\begin{array}{l}\text { Semibrean-English } \\
\text { ninim }\end{array}$ & Whole \\
Crotchet & Quarter \\
Quaver & Eighth
\end{tabular}

Source: School of Composition, 2020, How to read music (Part 1: Music notation), viewed 02 June 2020, from https://www.schoolofcomposition.com/music-notation/

to the first author's broader study into the ways of integrating music into mathematics.

The broader study and this article draw on two complementary views of curriculum integration: firstly, integration as 'a philosophy of teaching in which content is drawn from several subject areas to focus on a particular topic or theme' (Civil 2007:11), and secondly, integration as 'making connections across subject boundaries' (Drake \& Burns 2004 cited in Kneen et al. 2020). The following example illustrates making of connections between music and mathematics for the purpose of teaching the concept of equivalent fractions in parallel with teaching about (equivalent) note values. Learners can be shown that just as a whole is made up of eight eighths $\left(1\right.$ whole $\left.=\frac{1}{8}+\frac{1}{8}+\frac{1}{8}+\frac{1}{8}+\frac{1}{8}+\frac{1}{8}+\frac{1}{8}+\frac{1}{8}\right)$, so too, one whole note in music (a 'semibreve') is made up of eight eighth notes (or 'quavers') $(\mathrm{O}=\delta+\delta+\delta+\delta+\delta+\delta+\delta$ $+\delta)$. In this example, the same principles apply for adding like fractions or like note values to create a whole.

Curriculum integration of the sort described above is beneficial to the teaching and learning process because of its potential for (1) facilitating a deeper understanding of the fractional concepts (Civil 2007), (2) making meaningful connections between the subjects and (3) highlighting awareness of mathematical relationships in creative cultural forms of human activity. Landsberg, Krüger and Swart (2016) have also suggested a number of advantages of integration between subjects. These include benefits such as decreasing anxiety and fear in learners and increasing their participation and collaboration in meaningful experiences. Integration between subjects also has the potential for facilitating collaboration amongst teachers (Civil 2007).

In summary, the authors, along with a number of other researchers in education and mathematics education, support integration. It is, as noted, also a promoted principle of the South African curriculum. This study contributes ways for integrating mathematics and music to meet both the broader curriculum aims (e.g. appreciation of the beauty of mathematics and the recognition of mathematics as a creative human activity) and the specific aims of developing conceptual understanding of fractions. 
One of the assumptions that drive this research is the belief that visual, auditory and tactile-kinaesthetic representations can support learners' conceptual understanding of mathematics and that learning is enhanced through experiences that require learners to use all their senses. Many people have argued that this is important (see, for example, Claxton \& Murrel 1987; Fleming 1995; Raymond \& Pienaar 2013). Readings around such assumptions initiated the first author's search for theory to guide her action research study. She found Bresler's (1995) co-equal style of arts integration especially meaningful. It provided the conceptual argument for integrating music into the commonly labelled academic subjects at a pedagogical level rather than simply at an aesthetic level. This was what led her to choose Bresler's theory as a guide in almost every aspect of the intervention, from the design of strategies and LSMs through to the reflective criteria used and the data collection and data analysis decisions.

Integration is a 'concept whose fashion ebbs and flows sporadically' (Bresler 1995:1). It can also, as Bresler noted, 'mean very different things in terms of contents, resources, structures and pedagogies to different people' (1995:1). Bresler (1995) explains that the concept of integration between subjects can be traced back to the early 20th-century principles of progressive education. In the 1960s and 1970s, education goals evolved further to include the arts into the academic curriculum (Bresler 1995:1). Bresler (1995) cited the work of Dewey (1934) who encouraged that aesthetic experiences be part of the educational experience and also Broudy (1972) and Eisner (1982); Broudy envisioned the arts as a means to assist learners in perceiving their academic content as well as their environment around them; and Eisner suggested that different forms of representation (through visual, auditory and kinaesthetic means) enable learners to better interact with and understand the world in which they live. Benefits of curriculum integration identified by Bresler (1995) include increased participation, reflection, application of higher-order cognitive skills, application of art-specific skills and aesthetic appreciation.

As we noted in our introductory section, Bresler (1995), in her exploration of the ways in which the arts were taught in an interdisciplinary manner within the primary school curriculum, identified four integration styles. The first author saw the fourth of these styles, the co-equal style, as the most appropriate one for her action research study on mathematics and music integration. Its resonance derived from this style's recognition that learning from art forms and other subjects is of equal importance (Civil 2007). As noted previously, implementing a co-equal style of arts integration requires skills and knowledge of the arts forms, such as music, as well as the academic subject, such as mathematics, although, as Bresler (1995) indicated, an alternative strategy could be collaboration between specialist teachers towards achieving the goals of both subjects. The authors recognise that achieving such collaboration in preparing and implementing effectively integrated lessons may not be easy in some settings, which perhaps explains why Grumet et al. (2014) described the co-equal style as the most rigorous but the least prevalent approach. Given her specialism in music and qualification as a primary school mathematics teacher, the first author saw this latter point as constituting a research gap worthy of further exploration.

\section{Research methodology}

The study was conducted in an independent school in the Eastern Cape. Reddy et al. (2016:5) contrast independent schools to public schools in their report on the 2015 TIMSS study, noting that a significantly higher percentage of learners $(60 \%)$ in these schools achieved scores which demonstrated basic knowledge in mathematics. Reddy et al. (2016) attributed this to greater access to resources. A further factor making it possible for the first author to conduct this study at the school was that the management team actively encouraged teachers to experiment with teaching strategies, including taking advantage of opportunities for integration across the curriculum. Thus, it paved the way for her to trial strategies for linking the learning outcomes of music and mathematics.

The Grade 5 class comprised of 16 learners, eight boys and eight girls, all within the 11-12 year age range. This group of learners had diverse learning needs and socio-economic and cultural backgrounds. Because of the first author's prior experiences of working with this group of learners, she was aware of their different learning needs. The school's language of learning and teaching is English. Ten learners had English as their first language, and six faced the challenge of English being only their second or third language. Some other factors contributing to the diverse needs of the group were diagnoses by educational psychologists indicating that one learner had dyslexia, two learners had attention-deficit hyperactivity disorder and one was experiencing 'mathematics anxiety'.

Before beginning the intervention, the first author needed to ensure that her research design and conduct observed the ethical requirements both of the university and of research ethics more generally. Following the submission of a carefully considered ethics application, the university's ethical standards committee granted ethical clearance for this study. Applying for this clearance further stimulated the first author, as the action researcher, to critically reflect upon, and question, various aspects of the study from multiple perspectives. She carefully considered influences, which her personal involvement and her dual role as the researcher and research participant may have over the other participants in the study. Core ethical aspects addressed included obtaining gatekeeper permission from the school and ensuring clear explanation of all aspects of the study to critical peers, learners' guardians and the learners themselves. Thus, written, informed consent was secured from all participants. The first author emphasised to all participants that the focus of the action research design intentions was on her teaching strategies and LSMs, not the learners. She indicated that all participants had the right to withdraw from the study at any stage without prejudice. 
Learners', colleagues' and the school's anonymity was preserved by using pseudonyms. Finally, she ensured that there was no disruption to the school's normal programme. The mathematics lessons took place during school hours, according to the set timetable, and the first author remained mindful of the importance of maintaining focus on her regular teaching responsibilities.

The question guiding the first author's action research case study was as follows:

In what ways might my teaching around the inverse order relationship in unit fractions, at the Grade 5 level, be enriched by the inclusion of musical activities?

The study was qualitative in nature, influenced by an interpretivist paradigm acknowledging that individuals' lived experiences are shaped by their context and their perceptions about knowledge are socially constructed (Maxwell 2012; Thomas 2013; Willis 2007). It focussed on the design and implementation of a set of 10 Grade 5 mathematics lessons on fractions into which music was integrated, in ways that targeted skills in both subjects and in ways that allowed the first author to integrate the curriculum of both subject areas equally. The research question lent itself well to reflective processes of action research. Cycles of implementation of intervention strategies, reflection, adaptation and further implementation occurred (Ferrance 2000; Friedman, Gray \& Aragon 2018; McCallister 2018), guiding the first author in critically reflecting on her chosen strategies, the LSMs she developed and the ways in which this appeared to support the teaching of fractions to Grade 5s. Her critical reflections also assisted her in keeping the lessons at the co-equal style of integration with equal focus on both mathematics and music.

Given that the research question focussed on ways in which the first author could enrich her teaching of fractions, she acted as both the researcher and research participant in this action research case study, reflecting throughout each of the intervention cycles on her own teaching. Her learners were also research participants, and they provided feedback based on their experiences of the lessons. In addition, two of the first author's Grade 5 colleagues became research participants, having agreed to contribute by acting as critical peers. In this role, they viewed video recordings of critical moments from the lessons, identified by the first author, and discussed their insights on these with her. The study sample was thus both purposeful and convenient (Maxwell 2003), and the participants were ideally placed to provide the first author with rich feedback, understanding the dynamics and expectations present within their specific educational setting.

The reflective nature of action research (Ferrance 2000; Friedman et al. 2018; McCallister 2018) guided the first author to critically evaluate whether her lesson goals were achieved at the end of each lesson and to adjust her teaching strategies and LSMs across the course of the research cycle. Feedback from learners and critical peers contributed further to improvements for the following lesson of each cycle.

The 10 intervention lessons took place over an 8-week period. As Table 1 shows, the main focus in the first four

TABLE 1: Outline of intended goals, selection of learning support materials and challenges encountered across the 10-lesson unit.

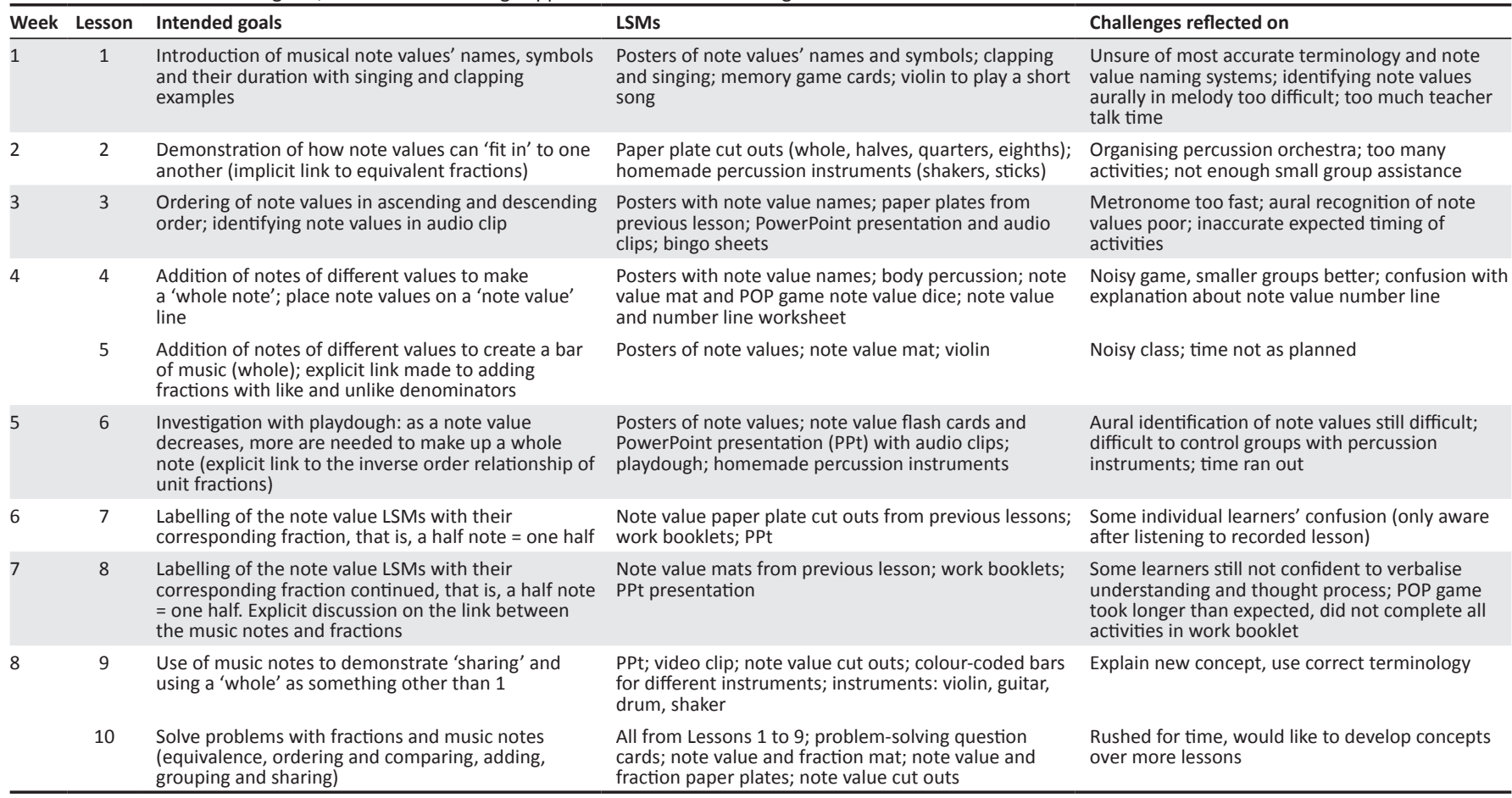

Source: Lovemore, T.S., 2020, 'Enriching my teaching around the inverse order relationship in unit fractions at the grade 5 level through the inclusion of musical activities: An action research case study', unpublished Master of Education thesis, Faculty of Education, Rhodes University, Grahamstown

LSMs, learning support materials. 
lessons was on music note values, thereby providing a necessary foundation for learners' transitioning across into explicit use of such knowledge in solving fraction problems (Lesson 5 onwards).

Multiple data collection tools from multiple sources were used to gain rich insight into this 10-lesson unit. Data sources included the first author's reflective research journal, video and audio recordings of intervention lessons, photographs, examples of learners' work, the learners' selfassessment feedback forms and informal oral feedback during the lessons as well as the voice-recorded semistructured interviews with critical peers (Mrs $\mathrm{H}$ and $\mathrm{Mr} \mathrm{K}$ are both Grade 5 teachers. Mrs $\mathrm{H}$ is in her early fifties, and $\mathrm{Mr} \mathrm{K}$ is in his mid-twenties). Triangulating across sources reduced the risk of bias deriving from any single source (Bush 2002; Ferrance 2000; Willis 2007), and, as Maxwell (2003:245) noted, 'cross-checking' across sources served to strengthen the credibility of a study.

After every second lesson, learners were asked to complete a self-assessment feedback form which asked them to indicate on a continuum on how they felt about the lesson in general, their level of understanding of the lesson content and their level of participation. Learners also had the opportunity to complete the written prompt, 'I want my teacher to know ...'. Three informal oral feedback sessions were held and voice recorded (at the beginning, middle and end of the 10-lesson intervention), where the first author invited her learners to discuss their general feelings about and experiences of the various lesson activities and the LSMs used.

Similarly, after every two lessons, the first author identified critical moments within the video recordings of the lessons and met with her Grade 5 critical peers to watch through the relevant sections with her and share their ideas about the successes and challenges in relation to the teaching strategies and LSMs. All nine (four individual and one combined) of these semi-structured interview sessions were recorded and subsequently transcribed. Through member checking (Brenner 2006; Willis 2007), the first author sought her critical peers' further feedback regarding the accuracy of her transcripts of these interviews.

The first author's own reflections (on lessons, on the feedback from the research participants and on examples of learners' work and photographs) recorded in her reflective research journal played a crucial role. Journal entries followed a template originally designed by the University of Birmingham's Academic Skills Centre (2015) based on Schön's principles of being a reflective practitioner (Schön 1983 , 1987). The first author's analyses and reflections on the strengths and areas for improvement after each lesson informed adjustments for subsequent lessons. Figure 2 depicts the broader action research cycle which she followed in her design of the lessons. Figure 3 shows some of the ways in which critical reflections informed subsequent lesson planning and implementation.

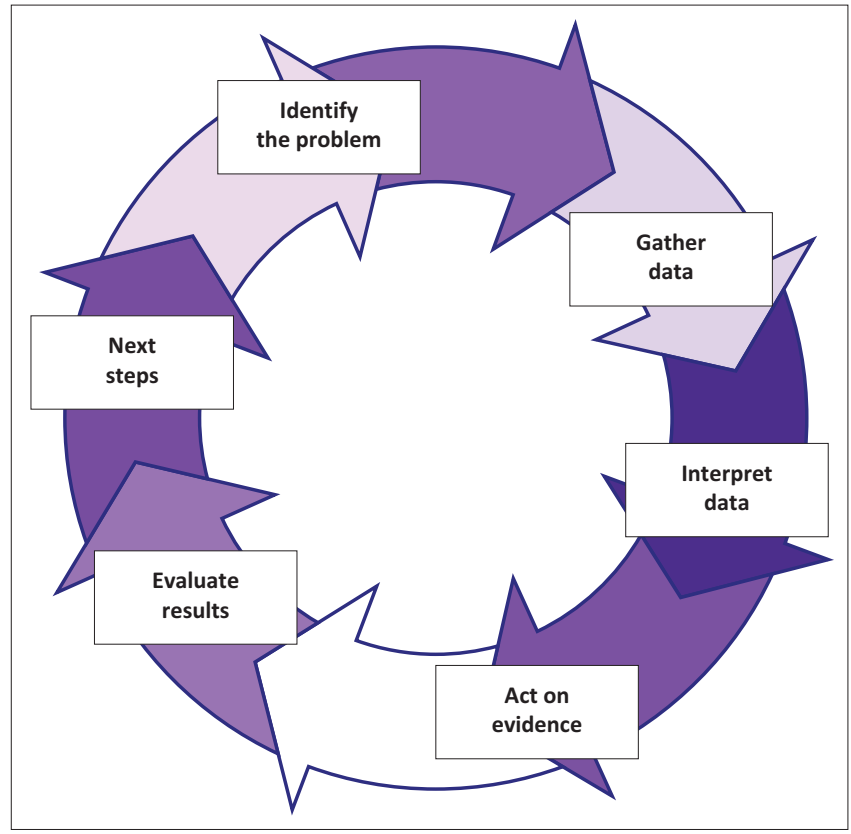

Source: Ferrance, E., 2000, Action research, Brown University, New York, NY FIGURE 2: Representation of cycles of reflection in action research.

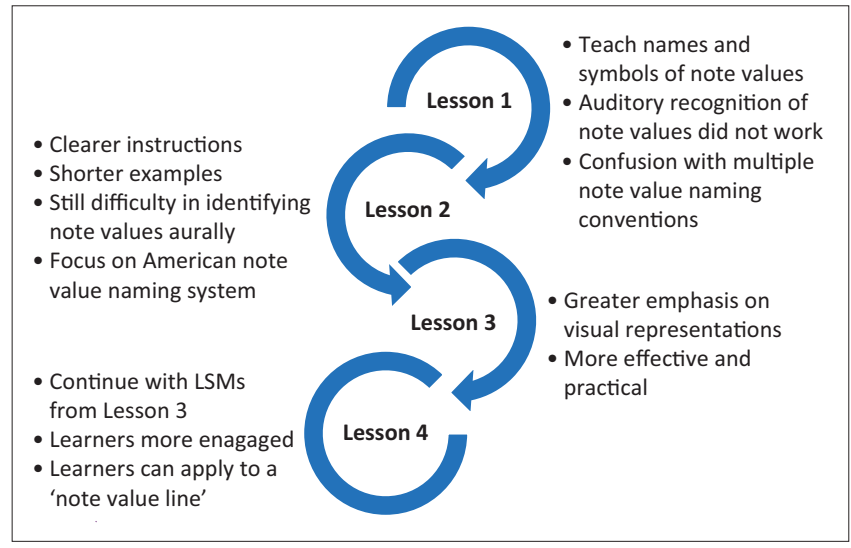

Source: Lovemore, T.S., 2020, 'Enriching my teaching around the inverse order relationship in unit fractions at the grade 5 level through the inclusion of musical activities: An action research case study', unpublished Master of Education thesis, Faculty of Education, Rhodes University, Grahamstown

FIGURE 3: Representation of the cycles of reflection, from the first author's reflective journal, exemplified through Lessons 1-4.

Some of the ways in which critical reflections informed the first author's subsequent lesson planning and implementation are shown in Figure 3.

Lessons 5-10 similarly included reflections and subsequent changes to lessons that followed. Examples of these reflections and changes are summarised in Table 2.

Analysis was an iterative and ongoing process throughout the study (Maxwell 2003). Because of the rich data collected from the intervention lessons and interviews, the first author needed to systematically analyse, interpret and present the ideas of the participants as authentically as possible (Friedman et al. 2018). Although it was time-consuming, she transcribed all the lessons and interviews herself, to develop a deeper understanding of and to make meaning from the rich data. Subsequently, two analytical frameworks based 
TABLE 2: Example changes and adaptations made through the cycles of reflection.

\begin{tabular}{ll}
\hline Lesson & Changes \\
\hline 5 & $\begin{array}{l}\text { Decision was made to make fractions more explicit in activities to follow; } \\
\text { timing of activities did not go as planned because of unexpected learner } \\
\text { discussion. }\end{array}$ \\
6 & $\begin{array}{l}\text { Realisation that the main focus does not need to be on aural identification } \\
\text { of note values, but rather on the link to fractions; equal emphasis should } \\
\text { now be placed on fractions, explicitly. }\end{array}$ \\
7 & $\begin{array}{l}\text { Although the link to fractions has been made explicit, learners need more } \\
\text { opportunities to practise linking note values and fractions, in order for the } \\
\text { note values to be useful as a resource for conceptual understanding. }\end{array}$ \\
8 & $\begin{array}{l}\text { Some learners are still not confident to verbalise understanding; the next two } \\
\text { sessions should focus on the 'whole' as something other than 1 (sharing). }\end{array}$ \\
9 & $\begin{array}{l}\text { Visual examples must be used to support auditory examples; the lesson } \\
\text { can now progress to focus on problem-solving with fractions. }\end{array}$ \\
10 & $\begin{array}{l}\text { Learners used a variety of strategies to solve problems; the link between } \\
\text { note values and fractions was discussed fully; there is room for further } \\
\text { exploration in future lessons. }\end{array}$ \\
\hline
\end{tabular}

Source: Lovemore, T.S., 2020, 'Enriching my teaching around the inverse order relationship in unit fractions at the grade 5 level through the inclusion of musical activities: An action in unit fractions at the grade 5 level through the inclusion of musical activities: An action
research case study', unpublished Master of Education thesis, Faculty of Education, Rhodes University, Grahamstown

on analysing video recordings were chosen to guide the analysis process. These were Adler and Ronda's (2015) framework for analysing mathematics discourse in instruction and the viewing, investigating and discussing environments of learning mathematics framework by Karsenty and Arcavi (2017). From these two frameworks, a colour-coded template (identifying the various sources of data) was developed, in which quotations, reflections and critical elements from the lessons could be recorded. For example, the research looked to answer questions such as: 'How did the LSMs add value to the lesson? How can they be improved?' and 'What links were established between mathematics and music? Did the musical activities support or hinder the teaching and learning of mathematics?'

This combination of analytical strategies and multiple data sources facilitated a clear and holistic interpretation of the broader study's findings. By systematically and iteratively working through the data, major elements and emerging themes were identified. For a full discussion of these findings, see Lovemore (2020). The 'thick description' (Geertz 1973) of the intervention lesson cycles shared there will, we hope, allow readers to immerse themselves sufficiently in the context of the study to make their own assessment of the overall credibility and relatability (Creswell \& Miller 2000:129) of the study's findings.

\section{Summary of findings}

From the process of data collection, presentation and analysis, the first author derived findings, which she grouped into five categories, based on repeated key phrases, as well as key elements within each category. A summary of these findings is shown in Table 3.

\section{Discussion of findings}

The focus for the present article is, as was indicated, the value of integrating music into mathematics lessons on fractions. In the discussion which follows, we highlight three aspects of this:

- opportunities for making connections across mathematics and music;
TABLE 3: The five categories of findings and key elements.

\begin{tabular}{|c|c|}
\hline Category & Key elements \\
\hline $\begin{array}{l}\text { 1. Teaching and } \\
\text { learning } \\
\text { strategies }\end{array}$ & $\begin{array}{l}\text { Integration: Critical peers noticed the potential for the integration } \\
\text { of music notes and fractions in the mathematics curriculum to be } \\
\text { beneficial to both subject areas. } \\
\text { Learning style theory: The musical activities provided a context in } \\
\text { which all learning styles could be included, by allowing for } \\
\text { multiple representations of fractions. }\end{array}$ \\
\hline $\begin{array}{l}\text { 2. Value of the } \\
\text { LSMs }\end{array}$ & $\begin{array}{l}\text { Most valuable LSMs were musical instruments, paper plates, note } \\
\text { value and fraction mat, note value number line, PowerPoint } \\
\text { presentations, work booklets and play dough. } \\
\text { These LSMs allowed for the note values to be linked, first } \\
\text { implicitly and later explicitly, to the fractions. } \\
\text { Learners enjoyed using the variety of LSMs to represent note } \\
\text { values, increasing motivation and hands-on participation. }\end{array}$ \\
\hline $\begin{array}{l}\text { 3. Activities from } \\
\text { music based to } \\
\text { fraction based }\end{array}$ & $\begin{array}{l}\text { Problem-solving activities: The last two lessons were intended to } \\
\text { combine the use of note values and fractions in a more balanced } \\
\text { way, in line with Bresler's co-equal style, where the musical } \\
\text { activities and LSMs supported the learning and application of } \\
\text { fractions. Mr K noted that Lesson } 9 \text { used music as a context in } \\
\text { which fractions can be applied. } \\
\text { Balanced focus on music and fractions: Critical peers indicated } \\
\text { that the music and mathematics had reached a point where they } \\
\text { were considered of equal importance in the lessons. }\end{array}$ \\
\hline $\begin{array}{l}\text { 4. Links between } \\
\text { the music } \\
\text { (note values) } \\
\text { and the } \\
\text { mathematics } \\
\text { (fractions) }\end{array}$ & $\begin{array}{l}\text { The American naming system for the note values lent itself well } \\
\text { to compare music notes to fractions. The practical musical } \\
\text { activities and examples as well as the LSMs led to clear links with } \\
\text { fractions, including the notion of iteration, equivalence, } \\
\text { comparing and ordering, adding fractions with unlike } \\
\text { denominators and the inverse order relationship in fractions. }\end{array}$ \\
\hline $\begin{array}{l}\text { 5. Reflections } \\
\text { on the action } \\
\text { research cycles }\end{array}$ & $\begin{array}{l}\text { Through the cycles of trialling, reflecting, adjusting and } \\
\text { re-trialling strategies and LSMs, the teacher found that this } \\
\text { intervention programme of } 10 \text { lessons had a positive effect on } \\
\text { her teaching around the inverse order relationship in unit } \\
\text { fractions. In the final lesson, it was interesting to see the variety } \\
\text { of methods that the learners used to solve the problems and } \\
\text { hear the group discussions and debates. }\end{array}$ \\
\hline
\end{tabular}

Source: Lovemore, T.S., 2020, 'Enriching my teaching around the inverse order relationship in unit fractions at the grade 5 level through the inclusion of musical activities: An action research case study', unpublished Master of Education thesis, Faculty of Education, Rhodes University, Grahamstown

LSMs, learning support materials.

- achieving a co-equal style of arts integration; and

- some benefits of curriculum integration.

Because this discussion section focusses so exclusively on action research and classroom-based data, we now replace the term 'first author' with 'teacher'. Whilst the research took place within the Grade 5 classroom of the teacher (in her mid-twenties), fractions are introduced in the South African curriculum in the foundation phase. The focus of the activities and the LSMs on using multiple and concrete representations invoking learners to employ multiple senses (auditory, verbal, visual, tactile and kinaesthetic) is particularly relevant to foundation phase learners. We, therefore, argue that the following themes that emerged from the research would likely similarly apply to the teaching of fractions through integration with music in foundation phase classrooms.

\section{Opportunities for connections to be made across mathematics and music}

In line with curriculum expectations, the teacher designed various LSMs to use in teaching learners the names of the note values. On the basis of reflection and observations of learners' discussions, she found that the fractional American note-naming convention worked more effectively (learners appeared, for example, to grasp the term 'eighth note' more easily than the term 'quaver'). An early learning task involved getting learners to compare and sequence the duration of different note values (recognising, for example, 
that three-quarter notes represent a longer duration than one-half note). Figure 1 shows the note value names and durations. Lessons included adding note values of like and unlike values to form a whole note duration and identifying the equivalent note values.

Throughout the intervention cycle, musical activities were linked to fractions. Although, at first, no link was explicitly made by the teacher, from the first lesson some learners were quick to recognise the connection between note values and fractions. The school's violin teacher (Mrs M) walked past the classroom and commented that 'music is maths'. This prompted a discussion where learners linked the music to the mathematics, as seen in the extract below:

Teacher: Why do you think Mrs M said that music is maths?

Liv: Because you also do fractions.

Teacher: Why are we using fractions?

Harry: To count the quarters, the halves and the whole.

(Lesson 1 transcript, 06 February 2019)

As the intervention cycle lessons continued, the connection between the two subjects became ever clearer. In the second critical peer interview, after Lesson 4, Mrs H commented on how the link between the music notes and fractions had strengthened, 'I can definitely in this lesson see more progression, and a clearer link or where you're going to, or what your aim is here' (Mrs H, Interview 2 of 5, 01 March 2019).

From Lesson 5, the link was made explicit by the teacher. In Lesson 3, the teacher had got the children to use paper plates to represent different note values (Figure 4). These paper plates were again used in Lesson 7 to link the note values to their corresponding fraction. The teacher got learners to overlay each of the earlier music-based activities onto learning about fractions (Figure 5). The whole note plate represented one whole, half note plates two halves, quarter note plates four quarters, eighth note plates eight eighths.
Another example of this overlaying procedure was in Lesson 8, when the 'note value line' was converted into a number line between zero and one (see Figure 6). At first, learners had difficulty placing the fractions on the number line. With the help of the note value mat, however, plus guiding prompts from the teacher, they managed. The extract below from Lesson 8 illuminates how the learners reasoned as to where to place the fractions on the number lines:

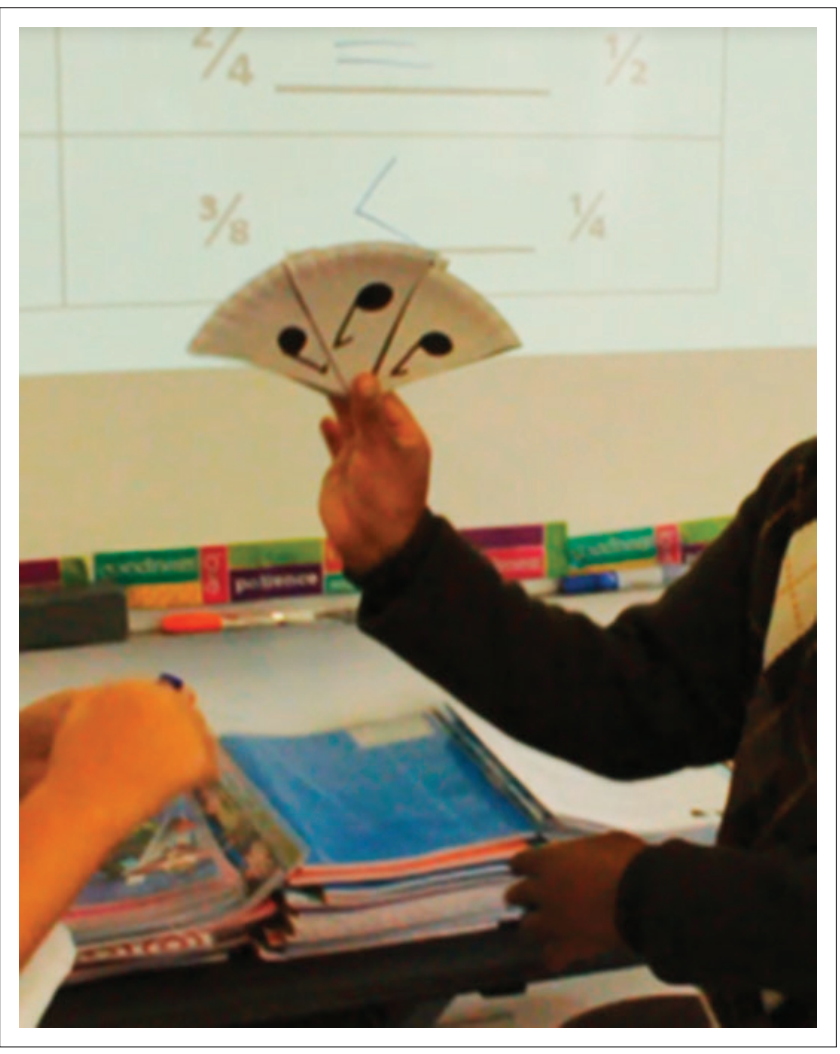

Source: Lovemore, T.S., 2020, 'Enriching my teaching around the inverse order relationship in unit fractions at the grade 5 level through the inclusion of musical activities: An action research case study', unpublished Master of Education thesis, Faculty of Education, Rhodes University, Grahamstown

FIGURE 5: Two learners demonstrating with paper plate learning support materials that three-eighth notes are longer than one-quarter note; therefore, $\frac{3}{8}$ is more than $\frac{1}{4}$.

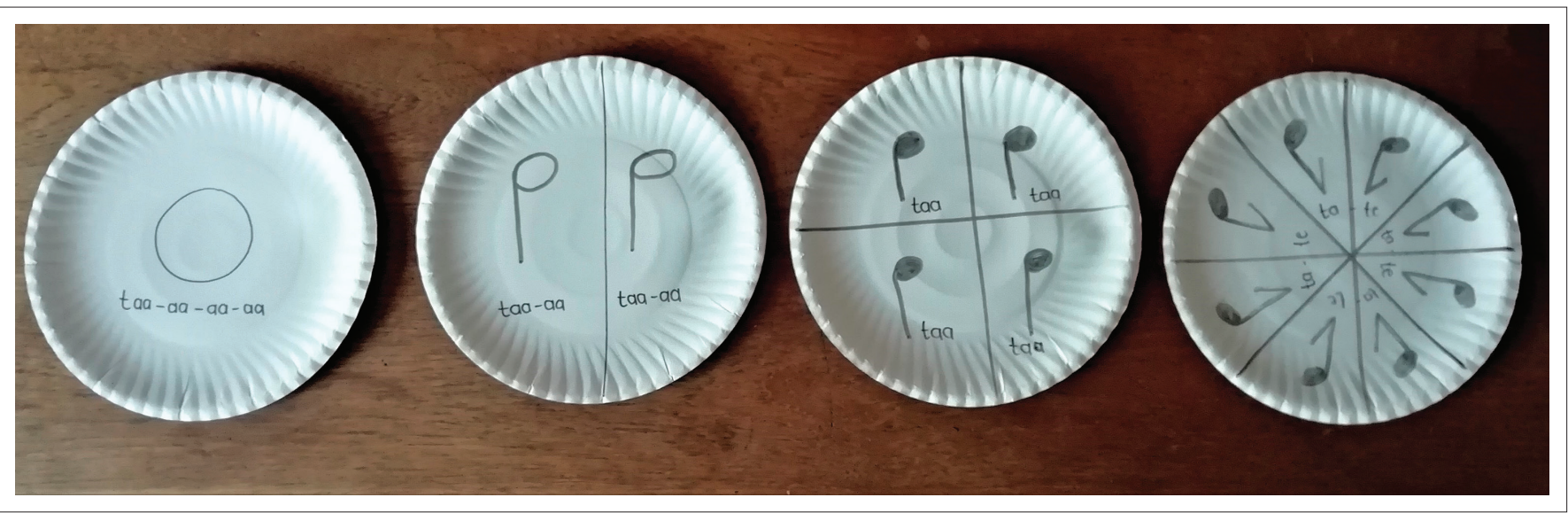

Source: Lovemore, T.S., 2020, 'Enriching my teaching around the inverse order relationship in unit fractions at the grade 5 level through the inclusion of musical activities: An action research case study', unpublished Master of Education thesis, Faculty of Education, Rhodes University, Grahamstown

FIGURE 4: Photograph of paper plate learning support materials to visually represent different note values. 


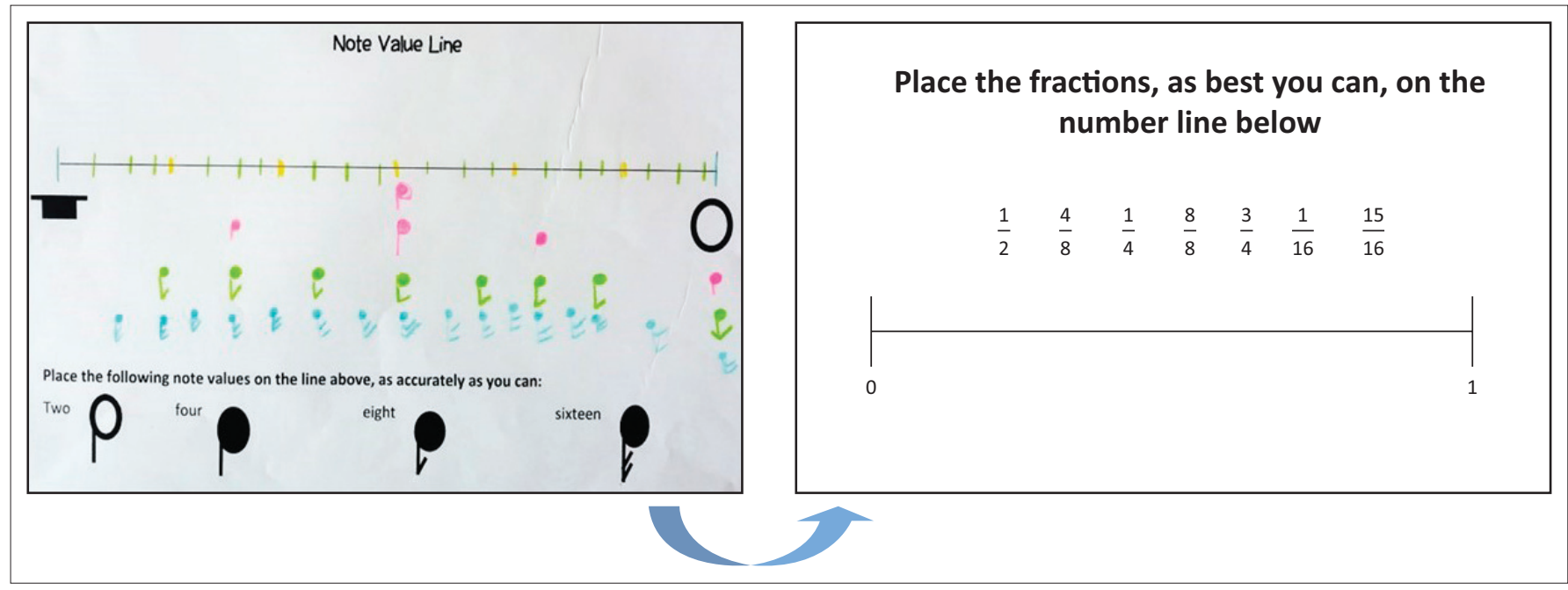

Source: Lovemore, T.S., 2020, 'Enriching my teaching around the inverse order relationship in unit fractions at the grade 5 level through the inclusion of musical activities: An action research case study', unpublished Master of Education thesis, Faculty of Education, Rhodes University, Grahamstown

FIGURE 6: Example of how the 'note value line' was used along with the number line between zero and one.

Teacher: So, what's the last fraction you have to label?

Anastasia: I think it's gonna be close to the one?

Teacher: Why do you think 15 sixteenths will be close to one whole?

Anastasia: Because if you had one more sixteenth it will be a whole.

Teacher: Exactly!

Ava: So, it should be here.

Teacher: Now, how are we going to find an accurate place? What strategy can we use?

Anastasia: Halve it and halve it again.

Teacher: Okay, because we know that this is a quarter (points), so if you're going to divide it into four, it will be sixteenths.

Anastasia: So, you're gonna halve it and halve it again?

Teacher: Yes, well done Anastasia!

(Lesson 8 transcript, 19 March 2019)

Additionally, throughout the lesson intervention cycle, and specifically in Lesson 6, music note values were used to demonstrate the concept of the inverse order relationship of unit fractions. Learners' participation and discussions showed that they were developing a deeper understanding of this, prompting $\mathrm{Mr} \mathrm{K}$, in the final interview, to note:

'I think the inverse relationship came through quite strongly where they had to divide the counts between the different instruments and when they could see the counts on the board.

So, if it had fewer notes, it could have been played over a longer period of time, depending on the note value. So, ja, I think the inverse relationship came through quite strongly.' (Mr K, Interview 5 of 5, 26 March 2019)

It was encouraging that the learners and critical peers recognised that a clear connection had been made across mathematics and music, which is supported by literature, as mentioned earlier (Civil 2007; Edelson \& Johnson 2003; Geist et al. 2012; Song et al. 2016). The teacher, in her reflections, noted that this indicated that her lessons had focussed on developing conceptual understanding of fractions, where learners could recognise fractions as more than 'two numbers separated by a line' (Musser et al. 2011) and following rules, to a deeper understanding of the relative value of a fraction, similar to that of a note value. Thus, the intervention lessons promoted the development of proportional reasoning, as advocated by Cortina et al. (2019), discussed above. In the following subsection, the balance between the two subjects according to a co-equal style of arts integration is discussed.

\section{Achieving a co-equal style of arts integration}

It was challenging to find an optimal balance between using music note values and fractions, thereby staying true to the co-equal style of arts integration (Bresler 1995). This is in line with the findings of Bresler (1995) and Song et al. (2016) who stated that teaching with the co-equal style is the most demanding form of integrating the arts with academic subjects. One of the critical peers, Mrs H, initially argued that the mathematics was benefitting the learning of music note values rather than the other way around. This was a concern the teacher had herself reflected on after each lesson. By the end of the 10-lesson intervention cycle, however, both critical peers noted that a balance had been achieved, mutually beneficial for the learning of both music and mathematics. After the critical peer discussion based on Lessons 6 and 7, the teacher, for example, noted in her reflective research journal:

'Mrs $\mathrm{H}$ was not convinced that the music is helping the maths in the [previous] interview. However, I feel that the intervention lessons should be looked at as a whole, which is possible now, after completing Lesson 8. I've noticed evidence of the music notes and LSMs helping support learners with the fractions. Mrs $\mathrm{H}$ and $\mathrm{Mr} \mathrm{K}$ have now both made similar observations in this interview.' (reflective journal entry by the teacher based on Mrs $\mathrm{H}$ and Mr K, Interview 4 of 5, 21 March 2019) 
The following comments from the critical peer interviews further highlight the balance between the mathematics and music and act as evidence of a co-equal strategy of integration (Bresler 1995):

'I do think they've helped each other, definitely ... because in the beginning there was lots of emphasis on the music, now there's more emphasis on the math ... there's definitely a link and the children can see the link between the two.' (Mrs H, interview 4 of 5, 21 March 2019)

'Ja, I think, you've definitely struck that balance now. I think, obviously you had to lay that foundation of music knowledge ... I mean, I think you struck like a very healthy balance between the music and the maths.' (Mr K, Interview 4 of 5, 21 March 2019)

Having satisfied herself that a balance had been found between the mathematics and music, the teacher analysed and reflected on the benefits that the integrated lessons appeared to have had overall.

\section{Benefits of curriculum integration}

In this subsection, we share some of the beneficial findings of this venture into cross-curricular integration.

\section{Real-life problem-solving opportunities}

The integration of mathematics and music provided an opportune context in which learners could see fractions being used in the real-life context of note values making up musical rhythms and melodies. The beauty of mathematics and mathematical relationships in the creation of music could also be explored, linking the activities to the broader mathematics curriculum aims, which is encouraged in the curriculum (DBE 2011a).

Learners could relate to the rhythm activities and enjoyed clapping the different note values. The examples of singing a note, such as in a choir, showed a real-life context where dividing a note into equal parts would be necessary. Mr K specifically noted the real-life connections learners had made in relation to their understanding of fractions within the context of music:

'I think it makes fractions more real world, like more real-life ... So, I think children are given practical examples now about how fractions can be used in everyday life, in music for example.' (Mr K, Interview 2 of 5, 01 March 2019)

Part of Lesson 10 focussed on solving problems involving fractional proportional reasoning, which were related to reallife examples in contexts other than music note values. The teacher's reasoning behind this decision was to observe whether learners could apply the conceptual understanding from the previous nine lessons to other examples. One of the critical moments that both the teacher and the critical peers reflected on was the way Messi (a learner who generally was not confident to participate in mathematics activities) participated in the lesson. He was the only one in his group to recognise that 4 out of 7 days, four-sevenths $\left(\frac{4}{7}\right)$, was the same as 8 out of 14 , eight-fourteenths $\left(\frac{8}{14}\right)$. Although the other learners thought that he was incorrect, he confidently argued his reasoning, showing his peers how he got to his answer through working with the proportion and recognising that the fractional representations were equivalent. This was a true 'Aha-moment' for him, as he often experienced mathematics anxiety (as recently diagnosed by an educational psychologist). This makes it all the more interesting that, during a critical peer interview, Mrs H specifically noted that Messi appeared 'more comfortable to work with the numbers, because he's learnt them as notes' (Mrs H, Interview 4 of 5, 21 March 2019). Both the teacher and the critical peers believed that working with music note values and fractions together gave Messi this confidence.

\section{Confidence}

Similar to the above example of Messi, the intervention cycle lessons helped other learners understand and gain confidence in their ability to tackle problems relating to both music note values and fractions. This relates to the advantage of curriculum integration described by Landsberg et al. (2016) who argue that it results in learners experiencing less fear and anxiety in mathematics lessons. Learners' self-assessment feedback forms indicated that they felt confident to work with the music note values and to use them in their mathematics lessons. Some of the learners commented that they were nervous working with fractions and were shy to ask for help, but that they liked the integrated approach, as seen in the comments from the written feedback of the following three learners:
It is better than doing normal fractions (Danny)
I hope to do other lessons like this one (Lionel)
I would like to do more music and a little bit of maths (Paige).
(Learner self-assessment feedback forms, 19 March 2019)

In an informal discussion towards the end of the intervention cycle, class opinion was divided relative to their preference of answering questions of music note values or replying with fraction names and notations. Some learners stated that they preferred 'doing fractions', some preferred 'doing music' and other learners commented that they did not have any preference, as they were the same. Examples of the variety of preferences can be seen in the following responses during Lesson 8:

Liv: Well the music notes are easier because it's like there's one whole. It's easier to put them together, because if you had, uhm, eight sixteenths and then you got [four] eighths it would be a whole. But for some people it takes a long time to figure out fractions.

Harry: Fractions ... Uh, it's easier to calculate.

Paul: Uhm, they the same, like two halves make a whole.

(Lesson 8 transcript, 19 March 2019)

It seems from such comments, therefore, that the integrated strategies allowed learners additional conceptual resources and representations for working with fractions, thereby 
increasing opportunities to learn and make sense of fractions, thus developing deeper understanding of the fractional concepts, as suggested by Civil (2007). By the end of the 10-lesson intervention cycle, learners had gained enough confidence to choose which method of representation they preferred, and they applied this knowledge to solving various fraction problems.

\section{Multiple representations and hands-on practical opportunities}

The use of music note values in representing fractions allowed for multiple representations to support learning. The lesson activities provided learners' visual, auditory, tactile and kinaesthetic opportunities for learning, which Eisner (1982) suggested would allow learners to better interact with and understand the world in which they live. Teaching strategies got learners to employ multiple senses: listening (auditory), singing (verbal), reading music note value rhythms (visual) and clapping (tactile and kinaesthetic). In Lesson 6, for example, learners used playdough as a resource to build note values. They made up bars of whole notes (by adding four-quarter notes, for example), clapped and sang the rhythms and used music note cards. This simultaneous use of multiple senses was something Mr K commented on:

'I think because you've involved the different senses a lot in the way that you've taught these last couple of lessons.' (Mr K, Interview 2 of 5, 01 March 2019)

Activities, such as the playdough one in Lesson 6 and the paper plate one in Lesson 3, also gave learners the opportunity to learn through practical, hands-on experiences with concrete resources. Many LSMs similarly allowed for learners to construct concrete fraction models, which they could first manipulate and then use in showing and explaining their reasoning:

Teacher: Paul, how did you know what to label each piece of card?

Paul: Uhm, Chanel said that, uhm, because like it was cut into sixteen, we had sixteenths.

Teacher: Okay, so you had sixteen pieces of card, sixteen notes, so there were sixteen in total. So, one of them would be ...?

Chanel: One sixteenth.

(Lesson 8 transcript, 19 March 2019)

Mrs $\mathrm{H}$ noted the benefit of comparing the relative sizes of the concrete models, such as the note value paper plates (see Figure 4) and note value and fraction mats. She also recognised the value the LSMs had in stimulating group discussions:

'Oh, it was nice discussion amongst the children and comparing fractions and, uhm, putting them [fraction mats] together, working out which one's bigger, smaller, in a practical way.' (Mrs H, Interview 4 of 5, 21 March 2019)

Mr K noticed similar value to the practical nature of the activities with the percussion orchestra and clapping:

'I also liked the practical application, that percussion game, when the one group was clapping the half notes and that group was clapping the quarter notes. I mean, effectively, it's the same as using the fraction mat, but now it becomes practical.' (Mrs H and Mr K (combined), Interview 3 of 5, 12 March 2019)

\section{Motivation and active involvement}

Learners appeared motivated to engage in the lesson because they were intrigued by the new resources and the music examples. They seemed excited hearing the violin and participating in clapping rhythms. A student teacher (Mr W), on observing the first lesson, noted the learners' intrigue at the novel resources:

'Uhm, I think it was exciting for the kids, because it's something new. Uhm, and they want to listen and they want to be involved. So, I thought they were very interactive and keen to do it.' (Mr W, Interview 1 of 2, 06 February 2019)

Similar positive feedback came from the informal discussion with learners after the first lesson:

Ava: We found it fun and interesting.

Chanel: It was not a boring maths lesson ...

Paul: It was different to our normal maths lesson.

(Lesson 1 transcript, 06 February 2019)

The following journal entry by the teacher resonated with learner comments:

'The learners were actively involved and motivated. There were many opportunities for me to identify misconceptions and to address them. I am happy that the learners were all actively involved in the group and individual activities.' (reflective journal entry by the teacer, 19 March 2019)

The active participation was beneficial for the teacher to make observations and evaluate learners' understanding. The critical peers shared similar observations with regard to the learner motivation and engagement. For example, they shared the following during their fourth interviews:

'Uhm, I think I've noticed now that all of them seem to be very happy to be involved.' (Mr K, Interview 4 of 5, 21 March 2019)

'Oh yes, they loved it. You can see it. Yes, all very good and the explanation, because even a child, like Lionel, you could see he was busy and engaged.'

'Yes, he generally doesn't get engaged and involved in lessons as much.' (Teacher)

'But he knew what was going on and could ask questions.' (Mrs H, Interview 4 of 5, 21 March 2019)

Practical activities, such as the music games and the problemsolving competition, motivated learners to engage, including those who were normally shy to participate. Commenting that learners' involvement in the lessons was a way to assess the success of the lessons, Mr K remarked on the progress that was evident throughout the lessons:

'I suppose one way of assessing the learners throughout these lessons and their understanding that they've gained would be through involvement. And I can definitely see, if you compare to Lessons 1 and 2, as opposed to now, it looked like all 
the learners were getting involved too.' (Mr K, Interview 5 of 5, 26 March 2019)

\section{Collaborative opportunities amongst learners and amongst teachers}

The explicit design for collaborative activities enabled those learners who were taking private music lessons to assist those who had not been exposed to music theory outside of the class music lessons. The following entry from the teacher's reflective research journal noted that the small group setting allowed for the music pupils to assist the nonmusic pupils to recognise and name the note values' (reflective journal entry, 06 February 2019). This collaborative space assisted in developing understanding of (1) how music note values work, (2) the concept of fractions in music note values and (3) the concept of fractions as applied to a range of abstract and applied mathematics problems.

The collaborative activities further encouraged group discussion amongst the learners and between the teacher and the learners. This increased collaboration and participation is similarly described by Landsberg et al. (2016) as an advantage of curriculum integration. It was interesting to observe learners debating and arguing their reasoning, which helped deepen the teacher's insight into their understanding. Such discussion also promoted opportunities for incidental learning in that a learner's question would often result in a critical teaching and learning moment for the whole class. These valuable teaching and learning moments helped guide the teacher in her subsequent intervention cycles of reflection, as she highlighted in the following comment to one of the critical peers:

'Yes, I learnt from them. They would mention something and I would say, I didn't even think of that! So, I learnt a lot from that incidental learning as well, and often it helped me to think of how I would do the next lesson.' (Mr K, Interview 5 of 5 , 26 March 2019)

As noted, the teacher had knowledge and skills in both subjects. During one of the critical peer interviews, however, concern was raised, as to how other mathematics teachers could implement similar integration strategies if they lacked the musical skills and knowledge. Whilst this highlights a limitation of the current study, it equally provides an opportunity for future research to explore ways in which mathematics and music teachers could collaborate on teaching fractions and note values in a meaningful, integrated manner. Mrs $\mathrm{H}$ highlighted, for example, that integration across the two subjects presented ideal opportunities for collaboration between teachers:

'There's a link between what's going on. I mean if my children were doing that in music and then came to [mathematics] class, it would make my job so much easier.' (Mrs $\mathrm{H}$ and $\mathrm{Mr} \mathrm{K}$ (combined), Interview 3 of 5, 12 March 2019)

This observation from Mrs $\mathrm{H}$ is consistent with the arguments made by both Bresler (1995) and Song et al. (2016) discussed earlier in the article, as teachers with specialisation within each subject can assist each other. Similarly, Civil (2007) notes integration across subjects promotes teacher collaboration.

\section{Conclusion}

As the foregoing discussion has shown, the integration of music into mathematics provided a way in which fractions could be represented other than the traditional representation of pizza or chocolate bars so commonly used in primary school lessons. Such integration, we argue, is beneficial in that it offers teachers an additional strategy to draw on in representing fractions.

This action research study was not about identifying generalised findings, but rather hoping that the findings spark interest and recognition by other teachers in other settings of the value of curriculum integration. We acknowledge that a potential limitation of this research could be that the first author was able to use her strong musical knowledge in the design and implementation of her fraction lessons. This limitation notwithstanding, we argue that integration of mathematics and music holds much potential for supporting student conceptual understanding of fractions and developing productive mathematical learning dispositions.

The question then would be to what extent these findings might be seen as useful to teachers without the necessary musical knowledge. Further research would be needed to find out whether other, non-musically trained, teachers could benefit from the use of these strategies and LSMs; for example, the use of the American note-naming convention may make it a manageable strategy for such teachers. We believe that collaborative working between music and mathematics teachers could overcome challenges that emerge for those teachers who do not have specialised knowledge of teaching both. Research can also be conducted on the use of fewer note values and lower number ranges of fractions to adapt the strategies for younger grade learners.

A key contribution of this article is that it shows curriculum integration as a means of achieving the broader curriculum aims of, for example, developing 'an appreciation for the beauty and elegance of mathematics' and recognising 'that mathematics is a creative part of human activity' (DBE 2011a:8). These aims, which hold for the mathematics curriculum at all levels, have tended to be overlooked despite their surviving the various curriculum revisions. In this action research case study, the teacher was able, and encouraged, to explore the creative link between music and mathematics, and the resulting integration provided an opportune space for the teacher, her learners and her critical peers to experience the beauty and creativity in mathematics. Our hope is that this article may inspire other teachers in developing their own integrated strategies and pedagogical innovations, through drawing on their talents, interests and competencies, to enrich their teaching of mathematics. Finally, we hope also that this article will provide some useful insights and suggestions for teachers interested in undertaking action research in their own classroom-based settings, and who, through systematic cycles of reflection and trialling, set out to explore and strengthen aspects of their own innovative teaching practices. 


\section{Acknowledgements}

This article is a product of a number of individuals' contributions who offered their time and insight into the various aspects of the study. The authors thank the headmaster of the school where the study was conducted as well as the guardians of the learners and the learners themselves. Two critical peers played a vital role in sharing their reflections; the authors appreciate their time.

\section{Competing interests}

The authors declare that they have no financial or personal relationships that may have inappropriately influenced them in writing this article.

\section{Authors' contributions}

The first author (T.S.L.) was a master of education student, supervised by the second author (S.-A.R), with the third author as co-supervisor (M.G.). This article emerged from the first author's master of education thesis. Whilst the first author carried out the actual writing, the second and third authors made considerable contributions to the discussions around the topic, responded to earlier drafts of the article and provided constructive suggestions regarding the overall content.

\section{Ethical consideration}

The first author submitted a written research proposal for consideration by her faculty's Higher Degrees Committee in August 2018. The University's Ethical Standards Committee of Rhodes University granted ethical clearance for this study (06 November 2018), which was then renewed for the following year (2019; ethical clearance number: Lovemore20181023).

\section{Funding information}

This research has been supported by the South African Research Chairs Initiative of the Department of Science and Technology and National Research Foundation (NRF) (Grant No. 74658). The NRF's financial assistance towards paying for the first author's studies is hereby acknowledged. Opinions expressed and conclusions arrived at are entirely the authors', however, and should thus not be attributed to the NRF.

\section{Data availability statement}

Data sharing is not applicable to this article as no new data were created or analysed in this article. Data from the first author's master's research work were used in the writing of this article.

\section{Disclaimer}

Opinions expressed and conclusions arrived at are entirely the authors', however, and should thus not be attributed to the NRF.

\section{References}

Adler, J. \& Pillay, V., 2017, 'Mathematics education in South Africa', in J. Adler \& A Sfard (eds.), Research for educational change: Transforming researchers' insights into improvement in mathematics teaching and learning, pp. 9-24, Routledge, London.

Adler, J. \& Ronda, E., 2015, 'A framework for describing Mathematics discourse in instruction and interpreting differences in teaching', African Journal of Research in Mathematics, Science and Technology Education 19(3), 237-254. https://doi.org/ 10.1080/10288457.2015.1089677

Brenner, M.E., 2006, 'Interviewing in educational research', quoted in J.L. Green, G. Camilli \& P.B. Elmore (eds.), Handbook of complementary methods in education research, pp. 357-370, Lawrence Erlbaum, Washington, DC.

Bresler, L., 1995, 'The subservient, co-equal, affective, and social integration styles and their implications for the arts', Arts Education Policy Review 96(5), 31-37. https://doi.org/10.1080/10632913.1995.9934564

Broudy, H.S., 1972, Enlightened cherishing, University of Illinois Press, Urbana, IL.

Bush, T., 2002, 'Authenticity - Reliability, validity and triangulation', in M. Coleman \& A. Briggs (eds.), Research methods in educational leadership and management, pp. 59-71, Sage, London.

Civil, M.D., 2007, 'Using music to improve learning in mathematics', Unpublished Master of Science in Education thesis, Department of Education and Human Development of the State University of New York College, Brockport, viewed 05 April 2018, from https://digitalcommons.brockport.edu/cgi/viewcontent. cgi $?$ article $=1276 \&$ context $=$ ehd_theses

Claxton, C.S. \& Murrell, P.H., 1987, Learning styles: Implications for improving educational practices, Association for the Study of Higher Education, Washington, DC.

Cortina, J., Visnovska, J., Graven, M. \& Vale, P., 2019, 'Instructional design in pursuing equity: The case of the "Fraction as Measure" sequence', in N. Govender, R. Mudaly, T. Mthethwa \& A. Singh-Pillay (eds.), Research for inclusive, relevant and equitable quality mathematics, science and technology education: Promoting research-based opportunity for all: Proceedings of the 27th Annual Conference of the Southern African Association for Research in Mathematics, Science and Technology Education (SAARMSTE), Durban, January 15-17, 2019, pp. 16-28.

Cortina, J.L., Visnovska, J. \& Zuniga, C., 2014, 'Unit fractions in the context of proportionality: Supporting students' reasoning about the inverse order relationship', Mathematics Education Research Journal 26(1), 79-99. https://doi. org/10.1007/s13394-013-0112-5

Creswell, J.W. \& Miller, D.L., 2000, 'Determining validity in qualitative inquiry', Theory into Practice 39(3), 124-131. https://doi.org/10.1207/s15430421tip3903_2

Department of Basic Education, 2011a, Curriculum and assessment policy statement: Mathematics Intermediate Phase Grade 4-6, Department of Basic Education, Pretoria.

Department of Basic Education, 2011b, Curriculum and assessment policy statement: Life Skills Intermediate Phase Grade 4-6, Department of Basic Education, Pretoria.

Department of Basic Education, 2019 , Diagnostic report 2018 - Part 1, Department of Education, Pretoria, viewed 05 April 2019, from htps://www.education.gov.za/ Education, Pretoria, viewed 05 April 2019, from https://www.education.gov.za/ LANGUAGES\%202018.pdf?ver=2019-01-24-125928-000.

Department of Basic Education, 2020, National senior certificate: School subject report, Department of Education, Pretoria, viewed 01 May 2020, from https:// www.education.gov.za/Portals/0/Documents/Reports/2019\%20NSC\%20 Www.education.gov.za/Portals/0/Documents/Reports/2019

Department of Education, 2003, Revised national curriculum statement grades $R$ - 9 (schools), Department of Education, Pretoria, viewed 29 February 2020 from https://www.gov.za/sites/default/files/gcis_document/201409/natcurO.pdf.

Dewey, J., 1934, Art as experience, Perigee Books, New York, NY.

Dole, S., 2010, 'Making connections to the big ideas in mathematics: Promoting proportional reasoning', in Teaching mathematics? Make it count: What research tells us about effective teaching and learning of mathematics, The Research Conference, Melbourne, August 16-17, 2010, pp. 71-74.

Edelson, R.J. \& Johnson, G., 2003, 'Music makes math meaningful', Childhood Education 80(2), 65-70. https://doi.org/10.1080/00094056.2004.10521259

Eisner, E., 1982, Cognition and curriculum, Longman, New York, NY.

Ferrance, E., 2000, Action research, Brown University, New York, NY.

Fleming, N.D., 1995, 'I'm different; Not dumb. Modes of presentation (VARK) in the tertiary classroom' in A. Zelmer (ed.), Research and development in higher education, Proceedings of the 1995 Annual Conference of the Higher Education and Research Development Society of Australasia (HERDSA), HERDSA, Rockhampton, Queensland, vol. 18, pp. 308-313.

Friedman, V.J., Gray, P. \& Aragon, A.O., 2018, 'From doing to writing action research: A plea to ARJ authors', Action Research Journal 16(1), 3-6. https://doi. org/10.1177/1476750318763041

Geertz, C., 1973, The interpretation of cultures, Basic Books, New York, NY.

Geist, K., Geist, E. \& Kuznik, K., 2012, 'The patterns of music: Young children learning mathematics through beat, rhythm, and melody', Young Children 67(1), 74-79, viewed 19 April 2020, from https://0-search.ebscohost.com.wam.seals.ac.za/ login.aspx?direct=true\&db=edsjsr\&AN=edsjsr.42731136\&site=eds-live.

Grumet, M.R., Randolph, D. \& Stanley, F., 2014, 'Arts integration: Reunion for a creative curriculum', in L. Bresler, M. Flemming \& J. O'Toole (eds.), The Routledge internationa handbook of the arts and education, pp. 268-279, Routledge, London. 
Hilton, A., Hilton, G., Dole, S. \& Goos, M., 2016, 'Promoting middle school students' proportional reasoning skills through an ongoing professional development propramme for teachers', Educational Studies in Mathematics 92(2), 193-219. programme for teachers', Educational Studies
https://doi.org/10.1007/s10649-016-9694-7

Karsenty, R. \& Arcavi, A., 2017, 'Mathematics, lenses and videotapes: A framework and a language for developing reflective practices of teaching', Journal of Mathematics Teacher Education 20(5), 433-455. https://doi.org/10.1007/ s10857-017-9379-x

Kneen, J., Breeze, T., Davies-Barnes, S., John, V. \& Thayer, E., 2020, 'Curriculum integration: The challenges for primary and secondary schools in developing new curriculum in the expressive arts', Curriculum Journal 31(2), 258-275. https:// doi.org/10.1002/curj.34

Kornfeld, J., 2005, Music notation and theory for intelligent beginners, viewed 09 April 2019, from https://jkornfeld.net/complete_theory_text.pdf.

Landsberg, E., Krüger, D. \& Swart, E., 2016, Addressing barriers to learning. A South African perspective, Van Schaik, Pretoria.

Lovemore, T.S., 2020, 'Enriching my teaching around the inverse order relationship in unit fractions at the grade 5 level through the inclusion of musical activities: An action research case study', unpublished Master of Education thesis, Faculty of Education, Rhodes University, Grahamstown.

Maxwell, J.A., 2003, 'Designing a qualitative study', in T.E. Hendrick, L. Brickman \& D.J. Rog (eds.), Applied research designs, pp. 214-253, Sage, Los Angeles, CA.

Maxwell, J.A., 2012, A realist approach for qualitative research, Sage, Los Angeles, CA.

McCallister, J., 2018, What is action research?, viewed 05 January 2018, from https:// study.com/academy/lesson/action-research-in-education-examples-methodsquiz.html.

Mlachila, M. \& Moeletsi, T., 2019, Struggling to make the grade: A review of the causes and consequences of the weak outcomes of South Africa's education system, International Monetary Fund, working paper 19/47, Government Printers, Pretoria.

Musser, G.L., Burger, W.F. \& Peterson, B.E., 2011, Mathematics for elementary teachers: International student version, 9th edn., Wiley, Hoboken, NJ.

Raymond, C.F. \& Pienaar, E.B., 2013, Making inclusive education work in classrooms, Pearson Education, Cape Town.

Reddy, V., Isdale, K., Juan, A., Visser, M., Winnaar, L. \& Arends, F., 2016, TIMSS 2015 Highlights of mathematics achievement of Grade 5 South African learners, HSRC Press, Cape Town.
Reddy, V., Winnaar, L., Juan, A., Harvey, J., Hannan, S., Namome, C. et al., 2020, TIMSS 2019: Highlights of South African grade 5 results in mathematics and science, Department of Basic Education, Pretoria, viewed 18 January 2020 , from http://www.timss-sa.org.za/download/TIMSS-2019_Grade-5_HSRC_ FinalReport.pdf.

Schön, D.A., 1983, The reflective practitioner: How professionals think in action, Basic Books, New York, NY.

Schön, D.A., 1987, Educating the reflective practitioner: Toward a new design for teaching and learning in the professions, Jossey-Bass Publishers, San Francisco, CA.

School of Composition, 2020, How to read music (Part 1: Music notation), viewed 02 June 2020, from https://www.schoolofcomposition.com/music-notation/.

Shay, S., 2020, 'Why South Africa's declining maths performance is a worry', The Conversation Africa, viewed 08 June 2020, from https://theconversation.com/ why-south-africas-declining-maths-performance-is-a-worry-129563.

Song, A.A., Tillman, D.A., Siemssen, A., Zhang, M., Lesser, L.M. \& Tinajero, J.V., 2016 'Learning to teach music-themed mathematics: An examination of preservice teachers' beliefs about developing and implementing interdisciplinary Mathematics pedagogy', Mathematics Teacher Education and Development 18(1), 20-36, viewed 19 April 2020, from https://0-search.ebscohost.com.wam.seals. ac.za/login.aspx?direct=true \&db=eric\&AN=EJ1103486\&site=eds-live.

Spaull, N., 2018, 'My Sunday Times article on Matric 2017', Sunday Times, 04 January viewed 25 June 2018, from https://nicspaull.com/2018/01/14/my-sunday-timesarticle-on-matric-2017/.

Thomas, G., 2013, How to do your research project: A guide for students in education and applied social sciences, Sage, London.

Tzur, R., 2016, 'On natural numbers and fractions: A reorganization (no bias) stance', in C. Csíkos, A. Rausch \& J. Szitányi (eds.), Proceedings of the 40th Conference of the International Group for the Psychology of Mathematics Education(PME), vol. 1 PME40, Szeged, Hungary, August 03-07, 2016, pp. 399-403.

University of Birmingham Academic Skills Centre, 2015, A short guide to reflective writing, viewed 13 May 2018, from https://intranet.birmingham.ac.uk/as/ libraryservices/library/skills/asc/documents/public/Short-Guide-ReflectiveWriting.pdf.

Willis, J.W., 2007, Foundations of qualitative research: Interpretive and critical approaches, Sage, Thousand Oaks, CA. 